\title{
Implementation of Facility Management to develop Education Quality
}

\author{
Asep Mumung ${ }^{1)}$, Iim Wasliman ${ }^{2)}$, Ikka Kartika ${ }^{3)}$, Ida Tedjawiani4) \\ 1. STIT Al-Hidayah Tasikmalaya \\ $2,3,4)$ UNINUS Bandung \\ *Coresponding Author \\ Email : asep.amung76@gmail.com
}

\begin{abstract}
The success of educational programs in schools is strongly influenced by the condition of educational facilities and infrastructure. Fulfilling the need for infrastructure facilities aims to describe and analyze planning, organizing, mobilizing, monitoring, as well as supporting and inhibiting factors for infrastructure management to develop the quality of education at RA Nurul Iman Majalengka. Qualitative research data collection techniques by means of observation, interviews, documentation and triangulation. Data analysis techniques: data collection, data reduction, data presentation and drawing conclusions. The findings of this research are planning with annual meetings, evaluating, reviewing work programs, implementing program activities and socializing the program to parents. Organizing: organizational structure, staffing, job descriptions and responsibilities, communication and coordination. Movement by procuring goods, inventory, maintenance, selection, reporting. Supervision by conducting evaluation and supervision as well as follow-up from supervision. Supporting factors: good design, employee placement, neat filing and involvement of madrasa supervisors. Inhibiting factors: the commitment of each human resource, lack of funds, complicated regulations and lack of employee skills development.
\end{abstract}

\section{Keywords: Infrastructure Management, Quality of Education}

\section{INTRODUCTION}

The learning process needs to be supported by the existence of complete and good educational facilities in schools. Because this will support the success of work programs and school activity programs in realizing educational goals. In addition, the use of educational facilities must be maximized properly and according to the purpose so that the use of these educational facilities can be used longer to support the teaching process in realizing learning objectives (Fuad, 2018).

It is also different when schools are large and advanced, the management of educational facilities is entrusted by special expert staff to handle and be optimally responsible for managing so that educational facilities can be used to support teaching activities efficiently and effectively. Educational tools that require special skills are transportation equipment, laptops, water, electricity, internet, telephone, laboratories, libraries, cooperatives, school health units, consumption/nutrition departments, and others. The bigger and more advanced the school, the greater the responsibility that must be carried out and borne by educational institutions in managing and developing management activities, the more educational tools must be provided to support teaching and learning activities to realize the school's vision (Mulyono, 2008). In line with the results of research conducted by Trisnawati, et al., (2019) which concluded that: (1) planning for facilities and infrastructure, namely by analyzing all school facilities and infrastructure first; (2) procurement of facilities and infrastructure to collect inventory data for previous data and find out inventory; (3) utilization / use is used by all school residents, teachers and all school students, the use of educational inventory must also be monitored effectively by parties appointed by the school; (4) maintenance of facilities and infrastructure is 
very much needed by teachers and students so that the goods owned by the school are always under supervision and well maintained; and (5) the elimination of infrastructure facilities by making a proposal letter to the Education Office so that the relevant parties can make an official report for deletion.

This study aims to describe and analyze planning, organizing, mobilizing, monitoring, supporting and inhibiting factors in order to measure how much the management of facilities and infrastructure contributes to developing the quality of education at RA Nurul Iman Majalengka.

\section{RESEARCH METHODS}

This research is a field research, namely data collection carried out by research at the place where the symptoms being investigated occur. Methodologically this research is descriptive qualitative, namely research that produces descriptive data in the form of written or spoken words from people and observed behavior (Arikuto, 2006). The data obtained by the researcher in this study were obtained using the following techniques: observation method, interview method, documentation method, and data triangulation method. Examination of the validity of the data used is a basic measure of assessment to check qualitative data (Moleong, 1993). These measures are: the degree of trust (credibility), transferability (transferability), dependability (dependability) and certainty (confirmability). The process of investigating an event to find out the actual situation in qualitative data, is carried out when data collection occurs, and after the end of data mobilization within a certain period of time. The data analysis used is a data analysis process from Miles and Huberman (in Sugiyono, 2012), which consists of data reduction, data presentation, and conclusions/checks about the truth of the report.

\section{RESULTS AND DISCUSSION}

Planning for School Facilities and Infrastructure in organizing the existence of educational facilities must consider educational facilities in accordance with applicable laws and regulations regarding the standard of educational facilities that must be owned by every school. The design process must include in order to solve five problems: (1) what to do; (2) why it is done; (3) how it is done; (4) where done; and (5) when to do it. Because a neat design will carry out the process of the company's vision and mission to be achieved. Spizer (in Munir and Wahyu, 2006) said that those who fail to plan, plan to fail (who are not successful in working on the design, in fact they are planning to fail). In designing school needs, the stages that we run begin with holding a meeting in July every year at the beginning of a new lesson where the annual agenda is program evaluation, implementing New Student Admission (PPDB), making programs, KTSP reviews, implementing learning, socializing learning programs to the student's guardian.

The design of educational facilities at RA Nurul Iman Majalengka is carried out by holding meetings, then evaluating programs, making programs, reviewing programs, socializing school work programs. The design carried out by RA Nurul Iman Majalengka is in accordance with what Jones (in Sulistyorini, 2009) stated that the design of the fulfillment of educational facilities in schools must begin by evaluating and analyzing the type of educational experience programmed by the school in the previous year. After that, action was taken to use the advantages to be further improved in the program in the current year.

Organizing Facilities and Infrastructure 
Organizing is placing behavioral bonds that bring results between personnel, as a result they can work together appropriately, carefully, efficiently and get personal conclusions in carrying out tasks in the existing environmental conditions in order to achieve certain goals and objectives. RA Nurul Iman Majalengka in this stage places teachers according to their competence and expertise. In addition, in enforcing the division of labor at RA, Nurul Iman Majalengka still uses multiple positions/dual jobs for all teachers as well as the head of RA.

The division of work that is applied at RA Nurul Iman Majalengka is that the teacher is not only a homeroom teacher but also the person in charge of the room/class to maintain and care for everything in their respective classes. In addition, teachers must carry out teaching, learning, training and guidance activities for students. The head of the madrasah sometimes also doubles as a counseling guidance teacher and even a class substitute teacher to replace the duties of teachers who are unable to attend school. In addition, in archiving all items in each room, it is also the duty of the teacher as the person in charge of the room/class. The stages of organizing carried out by RA Nurul Iman Majalengka include: (1) knowing the goals of the institution; (2) determine the activities needed to achieve institutional goals; (3) a group of (similar) activities are collected in one work unit; (4) determine the functions, duties, authorities, and responsibilities of each work unit; (5) determine the personal (number and expertise) of each work unit; and (6) establish a working relationship between work units. At the stage of organizing educational facilities/tools in the context of developing the quality of education at RA Nurul Iman Majalengka, it is carried out by compiling the organizational structure of the educational facilities section at RA Nurul Iman Majalengka by placing human resources in accordance with their competencies and expertise, outlining the duties and obligations as well as authorities and rights, are responsible for carrying out the main tasks and functions mandated by them and work together to communicate and coordinate with other human resources to carry out tasks, these responsibilities are in order to realize the ideals of RA Nurul Iman Majalengka.

RA Nurul Iman Majalengka applies the line and staff type of organization. The characteristics of line and staff organization are: (1) the organization is not small; (2) take part in the course of a complex series of activities; (3) a large number of employees with varying abilities and knowledge and skills; and (4) leaders and subordinates have an indirect working relationship, either due to the large number of human resources in the organization, or due to different locations. and far apart (Siagian, 2012). It requires a high level of managerial and technical operational expertise and skills in carrying out various activities.

Mobilization of Facilities and Infrastructure

The activity of mobilizing thoughts, energy among human resources, both involved and not involved, through cooperation in carrying out activities that have been designed to make the organization able to realize its goals effectively and efficiently. This stage is also one of a series of several stages of the management function. The driving function and implementation in other terms are: motivating (lifting the spirit); directing (determine the direction); influencing (influence); and commanding (giving command on orders) (Siagian, 2012). The work program of RA Nurul Iman Majalengka stated that in the 2018/2019 academic year the procurement of educational facilities was more focused on maintenance activities such as maintenance of the principal's office, maintenance of the teacher's room, maintenance of administrative rooms, maintenance of classrooms, maintenance of laboratory rooms, maintenance of library rooms, maintenance of buildings, maintenance of courtyards and gardens, maintenance of prayer rooms, maintenance of closed water (WC) and urinals, and maintenance of furniture. RA Nurul Iman Majalengka also followed the steps of the inventory activities disclosed by Bafadal (2000), including: (1) bookkeeping of educational equipment in the goods receipt book; (2) the use of special codes for tools classified as inventory items; and 
(3) all educational facilities in schools that are included in the inventory are recorded and reported. Elimination of educational facilities is carried out based on goods or tools that are no longer suitable for use, placed in the corner of the classroom because the school warehouse is no longer suitable to accommodate them, then the teacher who is also the person in charge of the room will report to the head of the madrasa to be followed up immediately and forwarded to the foundation whether the item is still available. can be repaired or direct sale of goods. Activities to mobilize the management of facilities and infrastructure to develop the quality of education at RA Nurul Iman Majalengka include: (1) procuring goods when urgent and important and must be available regardless of the work program that has been determined and ratified; (2) conduct an inventory and maintenance; (3) selection of goods that are still fit for use and those that are not suitable for use; (4) the person in charge of the room/classroom reports to the principal and is forwarded by reporting to the foundation to ask for a decision on further action to be taken; and (5) obtain a decision from the foundation on the condition that it is repaired if it can be repaired, and sold if it can no longer be repaired.

Supervision of Facilities and Infrastructure

Handayaningrat (2007) says that supervision is defined as an effort to determine what is being carried out by assessing the results or achievements achieved and if there are deviations from the predetermined standards, an improvement effort is immediately held, so that all the results or achievements achieved are in accordance with the plan. Control of educational facilities in the context of developing the quality of education at RA Nurul Iman Majalengka is to coordinate and communicate with the person in charge of the room/class together with the principal to determine the program, plan the monitoring program, schedule supervision, then ask each person in charge of the room/class to record neatly and regularly in a book. according to their respective lists and report to the principal. In addition, the principal also asks for help from the madrasa supervisor to monitor and assess the performance results of all teachers or those in charge of the room or class and provide suggestions and input. Then the principal conveys the input from the supervisor to the teacher as well as the person in charge of the room for immediate follow-up so that it doesn't happen again next year. In line with the statements and observations submitted and made by all teachers as well as the person in charge of the room/class that we must coordinate and establish communication to determine programs, monitoring program plans, scheduling supervision, we will be observed and assessed by supervisors both regarding how to teach students and see our administration book according to the tasks we carry out. Then the supervisor provides input, validates the documents that have been checked and gives value to the documents.

\section{CONCLUSION}

The findings that can be described from the results of this study include the following. Planning includes holding an annual meeting for new schools every July, evaluating the previous year's program, making school work programs for the current year, reviewing school work programs that will be implemented in the current year, as well as implementing and socializing the program to parents.

Organizing includes compiling the organizational structure of the infrastructure sector at RA Nurul Iman Majalengka, placing human resources in accordance with their competencies and expertise, outlining their duties and obligations as well as authorities and rights, being responsible for carrying out the main tasks and functions entrusted to them, working together to communicate and coordinate with other human resources to carry out the duties and responsibilities in order to realize the ideals of RA Nurul Iman Majalengka. Movement includes procuring goods when urgent and important and must be available regardless of the 
work program that has been determined and ratified, taking inventory and maintenance, selecting items that are still suitable for use and those that are not suitable for use, the person in charge of the room/class reports to the principal and forwarded with report to the foundation to ask for a decision on further action to be taken, obtain a decision from the foundation on the condition that it is repaired if it can be repaired, and sold if it can no longer be repaired.

Supervision includes coordinating and communicating with the person in charge of the room/class together with the principal determining the program, monitoring program plan, scheduling supervision, asking each person in charge of the room/class to record neatly and regularly in a book according to their respective lists, the person in charge is obliged to report activities to the principal, the principal asks for help from the madrasa supervisor to monitor and assess the performance results of all teachers or the person in charge of the room or class and provide suggestions and input, the principal evaluates and follows up so that it does not happen again next year.

\section{REFERENCES}

Arikunto, S. 2006. Prosedur Penelitian: Suatu Pendekatan Praktik. Jakarta: PT Rineka Cipta.

Bafadal, I. 2000. Manajemen Peningkatan Mutu Sekolah Dasar: Dari Sentralisasi Menuju Desentralisasi. Jakarta: Bumi Aksara.

Handayaningrat, S. 2007. Pengantar Studi Ilmu Administrasi dan Manajemen. Jakarta: Bina Aksara. Moeloeng, L. J. 2002. Metode Penelitian Kualitatif. Bandung: PT Remaja Rosdakarya.

Munir, \& Wahyu. 2006. Manajemen Dakwah. Jakarta: Kencana. Nurhattati, F. M. 2018.

Manajemen Sarana dan Prasarana Pendidikan: Konsep dan Aplikasinya. Depok: PT Raja Grafindo Persada. Prastyawan. 2016. Manajemen Sarana dan Prasarana Pendidikan, (Online), (http://ejournal.kopertais4.or.id/ pantura/index.php/alhikmah/article/view/2797), diakses 2 Mei 2019.

Siagian, S. P. 2012. Fungsi-fungsi Manajemen. Jakarta: Bumi Aksara.

Sugiyono. 2012. Metode Penelitian Pendidikan. Bandung: Alfabeta.

Sulistyorini. 2009. Manajemen Pendidikan Islam: Konsep, Strategi dan Aplikasi. Yogyakarta: Teras. 